\title{
Bacteriological quality of raw ewe's and goat's milk, with special references to foodborne pathogens
}

\author{
S. F. A. Abd El Aal and E. I. Awad \\ Food Control Department, Faculty of Veterinary Medicine, Zagazig University, Sharkya \\ Governorate, Egypt.
}

\begin{abstract}
Fifty raw ewe's and goat's milk samples (25 of each) were examined for total viable, psychrotrophic count and the presence of foodborne pathogenic microorganisms. The obtained results revealed that the mean total bacterial counts $/ \mathrm{ml}$ were $1.9 \times 10^{3}$ and $1.4 \times 10^{3}$ in the examined samples, respectively. Psychrotrophic bacteria could be detected in all examined samples $(\mathbf{1 0 0 . 0} \%)$ with mean values of $7.8 \times 10$ and $6.3 \times 10 / \mathrm{mL}$, respectively. Staphylococci, Enterococci, and $E$. coli, were detected in $(52.0 \& 84.0 \%),(44.0 \& 36.0 \%)$ and $(36.0 \& 44.0 \%)$ of the examined samples with mean values/ml of $(7.2 \times 10 \& 6.1 \times 10),(2.5 \times 10 \& 2.4 \times 10)$ and $(3.0 \times 10 \& 2.1 \times 10)$, respectively. The predominant isolated bacterial strains were Staphylococcus aureus, Staphylococcus epidermidis, Enterococcus faecalis, Enterococcus faecium and $E$. coli, at percentages of $(24.3 \& 19.2 \%),(16.2 \&$ $32.7 \%),(10.8 \& 13.5 \%),(19.0 \& 17.3 \%)$ and $(29.7 \& 17.3 \%)$ of total isolates, respectively. On the other hand, Clostridium perfringens, Campylobacter jejuni, Corynebacterium bovis and Salmonellae failed to be detected in all examined samples. The sanitary and public health importance of these organisms as well as preventive measures to improve the quality of milk and safeguard the consumers from infection were discussed.
\end{abstract}

Although the world production of goat's milk has been relatively minor when compared with total of bovine milk $(2.1 \%$ versus $84.6 \%$ of the total production, respectively), the worldwide goat population has reached 758 million heads with $55 \%$ increase during the last 20 years, and 12.2 million tons of goat's milk with $58 \%$ increasing during the same period (FAO, 2004). Also, more than two million metric tons of ewe's milk are produced in European Union (Herrero, 1999).

There are growing demands for ovine milk by consumers. This is due to the increasing number of children suffering from intolerance to cow's milk (Zweifel et al., 2005). Ewe's and goat's milk are currently gaining considerably in economic importance, particularly in Mediterranean countries, as a result of growing acceptance of products made from them, mainly cheeses (Miguel et al., 1997).In developing countries, the production of these types of milk are coming to be useful strategy to tackle the problem of under nutrition, especially among the infant population (Haenlein, 2004).

In most regions ovine milk is used for production of cheese and salted yoghurt, which is one of the most liked traditional dairy products because it is smoother and whiter as compared with cow's milk product, higher digestibility, distinct alkalinity, higher buffering capacity, and certain therapeutic value in medicine and human nutrition (Haenlein, 2004).

The microbiological characteristics of ovine milk differ from bovine milk in certain respects. Such factors as the larger number of head per volume of milk production (low level of production per head), the large number of head per flock, feeding, the milking process (the difficulty involved in machine milking), the conditions under which the herds or flocks are raised, adverse climatic conditions and the spread of production over a wide geographic area ect., all increase the difficulty of establishing good sanitary practices during milk production (Salmeron et al., 2002). According to compositional differences between the milk from cows, goats and ewes, quality standards adjusted and evaluated for specifics of small ruminant's milk should be considered (Morgan et al., 2000). The microbiological standard set by E C Directive 71/96 indicates a maximum permissible total count of $5 \times 10^{5} \mathrm{cfu} / \mathrm{ml}$ for raw ovine milk intended for direct use in manufacturing of dairy products (DOCE, 1994).

Raw ovine milk has been implicated as an important source of infection with the common bacterial agents associated with gastroenteritis as Salmonella spp, Staphylococci, Enterococci, and 
E. coli (Tamblyn, 1986). In view of food safety and consumer health protection, however, evaluation of microbiological status of ewe's and goat's milk and to evaluate whether possible foodborne pathogens are associated with these types of milk.

\section{Materials and methods}

Collection of samples. Fifty raw ewe's and goat's milk samples ( 25 of each) were collected from the Lindenhof farm of Hohenheim University. The samples were collected aseptically (about $50 \mathrm{ml}$ each) in clean, dry and sterile sampling bottles which placed in an insulated sampling case containing ice to ensure a storage temperature $4^{\circ} \mathrm{C}$ and transported to the laboratory of Umwelt und Teirhygiene Institute for bacteriological examination.

Preparation of samples. Each sample of milk was thoroughly mixed before being subjected to bacteriological examination. One $\mathrm{ml}$ of each prepared sample was added to $9 \mathrm{ml}$ of sterile saline to make serial decimal dilutions (A.P.H.A., 1992).

\section{Bacteriological examination.}

Total colony count (A.P.H.A., 1992). $0.1 \mathrm{ml}$ from the previously prepared dilution was inoculated onto duplicates of standard plate count (SPC) agar and incubated at $37^{\circ} \mathrm{C}$ for $24-$ $48 \mathrm{hrs}$.

Enumeration of psychrotrophic microorganisms (A.P.H.A., 1992). From each previously prepared serial dilution of the samples $0.1 \mathrm{ml}$ was inoculated onto duplicates of standard plate count agar medium. Both inoculated and control plates were incubated at $7^{\circ} \mathrm{C}$ for 10 days. Total psychrotrophic count $/ \mathrm{ml}$ of examined samples were calculated and recorded.

Staphylococci count (Chapman, 1945). $0.1 \mathrm{ml}$ from the previously prepared dilutions of the examined samples was transferred and evenly spread on the surface of Mannitol salt agar medium (Oxoid, 1990) plates. Inoculated plates were incubated at $37^{\circ} \mathrm{C}$ for $48 \mathrm{~h}$. and Staphylococci count $/ \mathrm{ml}$ was calculated and recorded.

Enterococci count (Gelsomino et al., 2003). 0.1 $\mathrm{ml}$ from the previously prepared dilutions of the examined samples was inoculated on the surface of kanamycin esculin azide agar (kAA; Merck, Darmstadt, Germany). Inoculated plates were incubated at $37^{\circ} \mathrm{C}$. Counts were determined after $24 \mathrm{~h}$ incubation. black and gray colonies were counted. Total Enterococci counts $/ \mathrm{ml}$ of examined samples were calculated and recorded.
E. coli count. $0.1 \mathrm{ml}$ from the previously prepared dilutions of the examined samples was spread onto Targitol medium and Endo medium (Oxoid, 1990) which incubated at $37^{\circ} \mathrm{C}$ for 24 hrs.

Isolation of Salmonella spp. (Jayarao and Henning, 2001).

Pre-enrichment. $25 \mathrm{ml}$ milk sample were added to $225 \mathrm{ml}$ peptone water with Novobiocin (Standard: $100 \mathrm{mg} / 1 \mathrm{ml}$ sterile D.W. \& Test: 0.9 $\mathrm{ml}$ prepared solution/225) then incubated at $37^{\circ} \mathrm{C}$ for $24 \mathrm{hrs}$.

Selective enrichment. $1 \mathrm{ml}$ peptone water from previously prepared pre-enrichment was added to $10 \mathrm{ml}$ Rappaport Vassiliadis broth, Difco Laboratories (Two tubes) after that one tube was incubated at $37^{\circ} \mathrm{C}$ for $24 \mathrm{~h}$. and the second at $43^{\circ} \mathrm{C}$ for $24 \mathrm{hrs}$.

Plating on selective medium. $0.1 \mathrm{ml}$ of incubated Rappaport evenly spread on the surface of Xylose Lysine Desoxycholate (XLD) and Brillient Green Phenol Red Lactose Sucrose (BPLS) plates, Unipath Co. Inoculated plates were incubated at $37^{\circ} \mathrm{C}$ for $24 \mathrm{~h}$ and $43^{\circ} \mathrm{C}$ for $24 \mathrm{hrs}$.

Anaerobic spore formers count. Using Thioglucolate medium (Oxoid, 1990). $1 \mathrm{ml}$ milk sample was inoculated in 3 tubes of Thioglucolate broth, heating at $70^{\circ} \mathrm{C}$ for 20 min and incubated at $37^{\circ} \mathrm{C}$ for $24 \mathrm{~h}$. anaerobically (anaerobic jar with anaerocult A sachet moisted with $17 \mathrm{ml} \mathrm{D.W.).}$

$1 \mathrm{ml}$ from the previously prepared dilution was inoculated in 3 tubes of Thioglucolate broth, heating at $70^{\circ} \mathrm{C}$ for $20 \mathrm{~min}$ and incubated at $37^{\circ} \mathrm{C}$ for $24 \mathrm{~h}$. anaerobically.

Isolation and Identification of Campylobacter (Hunt et al., 2001).

Selective enrichment. $1 \mathrm{ml}$ milk sample was added to $9 \mathrm{ml}$ Preston selective enrichment broth which incubated at $43^{\circ} \mathrm{C}$ for $48 \mathrm{~h}$. in microaerophilic atmosphere (anaerobic jar with anaerocult $\mathrm{C}$ sachet of micoaerophilic organism moisted with $6 \mathrm{ml}$ D.W.), Oxoid Ltd., Basing Stoke, UK.

Plating on selective medium. $0.1 \mathrm{ml}$ of Preston selective enrichment broth was added on filter type AC (pore size, $0.45 \mu \mathrm{m}$ ) on the surface of Campylobacter agar medium (Columbia Agar Base + Horse Blood + Campylobacter Selective Supplement Cod SR 204 E + Campylobacter Growth Supplement Code SR 084 E) which incubated at $37^{\circ} \mathrm{C}$ for $2 \mathrm{~h}$. then removed the filter 
Table (1): Statistical analytical results of total colony counts/ml in examined raw ewe's and goat's milk samples.

\begin{tabular}{|c|c|c|c|c|c|}
\hline \multirow{2}{*}{ Samples } & \multirow{2}{*}{$\begin{array}{c}\text { No. of } \\
\text { examined } \\
\text { samples }\end{array}$} & \multicolumn{4}{|c|}{ Count $/ \mathrm{ml}$} \\
\hline & & Min. & Max. & Mean & S.E.M. \pm \\
\hline Ewe's milk & 25 & $1.0 \times 10^{2}$ & $1.5 \times 10^{4}$ & $1.9 \times 10^{3}$ & $0.60 \times 10^{3}$ \\
\hline Goat's milk & 25 & $2.0 \times 10^{2}$ & $9.0 \times 10^{3}$ & $1.4 \times 10^{3}$ & $0.47 \times 10^{3}$ \\
\hline
\end{tabular}

Table (2): Statistical analytical results of psychrotrophic bacteria counts/ml in examined raw ewe's and goat's milk samples.

\begin{tabular}{cccccccc}
\hline & \multirow{2}{*}{$\begin{array}{c}\text { No. of } \\
\text { examined } \\
\text { samples }\end{array}$} & \multicolumn{2}{c}{$\begin{array}{c}\text { Positive } \\
\text { samples }\end{array}$} & \multicolumn{4}{c}{ Count $/ \mathbf{m l}$} \\
\cline { 3 - 8 } & & No. & $\%$ & Min. & Max. & Mean & S.E.M. \pm \\
\hline Ewe's milk & 25 & 25 & 100.0 & $1.5 \times 10$ & $9.0 \times 10^{2}$ & $7.8 \times 10$ & $3.5 \times 10$ \\
Goat's milk & 25 & 25 & 100.0 & $1.3 \times 10$ & $8.1 \times 10^{2}$ & $6.3 \times 10$ & $3.1 \times 10$ \\
\hline
\end{tabular}

Table (3): Statistical analytical results of Staphylococci counts/ml in examined raw ewe's and goat's milk samples.

\begin{tabular}{cccccccc}
\hline \multirow{2}{*}{ Samples } & $\begin{array}{c}\text { No. of } \\
\text { examined } \\
\text { samples }\end{array}$ & \multicolumn{2}{c}{$\begin{array}{c}\text { Positive } \\
\text { samples }\end{array}$} & \multicolumn{4}{c}{ Count $/ \mathbf{m l}$} \\
\cline { 3 - 8 } & & No. & $\mathbf{\%}$ & Min. & Max. & Mean & S.E.M. \pm \\
\hline Ewe's milk & 25 & 13 & 52.0 & $1.0 \times 10$ & $4.7 \times 10^{2}$ & $7.2 \times 10$ & $2.5 \times 10$ \\
Goat's milk & 25 & 21 & 84.0 & $1.0 \times 10$ & $4.4 \times 10^{2}$ & $6.1 \times 10$ & $2.5 \times 10$ \\
\hline
\end{tabular}

Table (4): Statistical analytical results of Enterococci counts/ml in examined raw ewe's and goat's milk samples.

\begin{tabular}{|c|c|c|c|c|c|c|c|}
\hline \multirow{2}{*}{ Samples } & \multirow{2}{*}{$\begin{array}{c}\text { No. of } \\
\text { examined } \\
\text { samples }\end{array}$} & \multicolumn{2}{|c|}{$\begin{array}{l}\text { Positive } \\
\text { samples }\end{array}$} & \multicolumn{4}{|c|}{ Count $/ \mathrm{ml}$} \\
\hline & & No. & $\%$ & Min. & Max. & Mean & S.E.M. \pm \\
\hline Ewe's milk & 25 & 11 & 44.0 & $1.0 \times 10$ & $9.0 \times 10$ & $2.5 \times 10$ & $0.47 \times 10$ \\
\hline Goat's milk & 25 & 9 & 36.0 & $1.0 \times 10$ & $4.0 \times 10$ & $2.4 \times 10$ & $0.23 \times 10$ \\
\hline
\end{tabular}

Table (5): Statistical analytical results of $E$. coli counts/ml in examined raw ewe's and goat's milk samples.

\begin{tabular}{|c|c|c|c|c|c|c|c|}
\hline \multirow{2}{*}{ Samples } & \multirow[t]{2}{*}{$\begin{array}{c}\text { No. of } \\
\text { examined } \\
\text { samples }\end{array}$} & \multicolumn{2}{|c|}{$\begin{array}{l}\text { Positive } \\
\text { samples }\end{array}$} & \multicolumn{4}{|c|}{ Count $/ \mathrm{ml}$} \\
\hline & & No. & $\%$ & Min. & Max. & Mean & S.E.M. \pm \\
\hline Ewe's milk & 25 & 9 & 36.0 & $1.0 \times 10$ & $7.0 \times 10$ & $3.0 \times 10$ & $0.41 \times 10$ \\
\hline Goat's milk & 25 & 11 & 44.0 & $1.0 \times 10$ & $5.0 \times 10$ & $2.1 \times 10$ & $0.32 \times 10$ \\
\hline
\end{tabular}


Table (6): Incidence of isolated bacterial stains in examined raw ewe's and goat's milk samples.

\begin{tabular}{lcccc}
\hline \multirow{2}{*}{ Isolated bacterial stains } & \multicolumn{2}{c}{ Ewe's milk } & \multicolumn{2}{c}{ Goat's milk } \\
\cline { 2 - 5 } & No. & $\mathbf{\%}$ & No. & \% \\
\hline Staph. aureus & 9 & 24.3 & 10 & 19.2 \\
Staph. epidermidis & 6 & 16.2 & 17 & 32.7 \\
Entrococcus faecalis & 4 & 10.8 & 7 & 13.5 \\
Entrococcus faecium & 7 & 19.0 & 9 & 17.3 \\
E. coli & 11 & 29.7 & 9 & 17.3 \\
Clostridium perfringens & 0 & 0.0 & 0 & 0.0 \\
Campylobacter jejuni & 0 & 0.0 & 0 & 0.0 \\
Corynebacterium bovis & 0 & 0.0 & 0 & 0.0 \\
Salmonellae & 0 & 0.0 & 0 & 0.0 \\
\hline
\end{tabular}

and the media were incubated at $43^{\circ} \mathrm{C}$ for $48 \mathrm{~h}$. microaerophilic in anaerobic jar.

Isolation and Identification of Corynebacterium. $0.1 \mathrm{ml}$ from the previously prepared dilutions of the examined samples was spread onto blood agar plates $(5 \%$ defibrinated sheep blood). Plates were incubated aerobically at $37^{\circ} \mathrm{C}$ and examined after $24 \mathrm{~h}$.

Identification of isolated organisms. Purified colonies were identified by using colony morphology, gram staining characteristics, oxidase, Catalase, coagulase production and biochemical reactions. Specific identifications were made using Commercial micro methods (API Staph for Staphylococci, API 20 Strept for Enterococci, API $20 \mathrm{E}$ for E. coli, API $20 \mathrm{~A}$ for Clostridia, API Campy, and API Coryne, Bio Merieux, France). Specific serological tests were conducted for Salmonellae spp.: polyvalent (I or II) and monovalent.

\section{Results and Discussion}

Results listed in Table (1) revealed that the total bacterial counts/ $\mathrm{L}$ of examined ewe's and goat's milk samples were ranged from $1.0 \times 10^{2}$ to $1.5 \times 10^{4}$ and $2.0 \times 10^{2}$ to $9.0 \times 10^{3}$ with mean values of $1.9 \times 10^{3}$ and $1.4 \times 10^{3}$, respectively. Higher total bacterial count in ewe's milk was obtained by (Abo-Elnaga et al., 1985) while, higher total bacterial counts in both types were reported in goat's milk (Roberts, 1985; Faschino et al., 2002; Muehlherr et al., 2003; Zweifel et al., 2005). The lower value of total bacterial count in goat's milk was obtained by (Zeng and Escobar 1996).

From the previously listed results, it is observed that any problem with ewe's and goat's milk may be related to poor hygiene during the production rather than transmission of organisms from the animal itself.

Results presented in Table (2) showed that psychrotrophic bacterial counts $/ \mathrm{ml}$ in examined samples of ewe's and goat's milk were ranged from $1.5 \times 10$ to $9.0 \times 10^{2}$ and $1.3 \times 10$ to $8.1 \times 10^{2}$ with mean values of $7.8 \times 10$ and $6.3 \times 10$, respectively. The presence of large numbers of psychrotrophic organisms is not necessarily indicative of an immediate health hazard because pasteurisation kills virtually all of the thermolabile psychrotrophs but it does indicate a lack of good sanitary practices where the growth and metabolic activity originating from post pasteurisation contamination that give rise to spoilage, loss of quality or create a health hazard (James et al., 1973; Sorhaug and Stepaniak, 1997).

The results summarized in Table (3) decleared that the Staphylococcus spp. could be detected in 52.0 and $84.0 \%$ of examined ewe's and goat's milk samples with mean values of 7.2 $\mathrm{x} 10$ and $6.1 \mathrm{x} 10$, respectively. Lower percentages and lower counts $/ \mathrm{ml}$ were reported (Abo-Elnaga et al., 1985; Roberts, 1985; Little and De Louvois, 1999; Muehlherr et al., 2003) while, higher counts were reported by (Faschino et al., 2002; Holeckova et al., 2004). The main isolated Staphylococci strains were Staphylococcus aureus and Staphylococcus epidermidis at percentages of (24.3 \& $19.2 \%)$ and (16.2 \& $32.7 \%)$ of total isolates, respectively (Table, 6). Highest Staphylococci count is good indication of clinical udder alteration Deinhofer and Pernthaner, 1993 because one of the important causes of mastitis either in ewes or goats is staphylococci (Smith and Roguinsky, 1977). 
The results tabulated in Table (4) revealed that the enterococci could be detected in 44.0 and $36.0 \%$ of examined ewe's and goat's milk samples with mean values of $2.5 \times 10$ and 2.4 $\mathrm{x} 10$, respectively. Higher enterococci counts were reported by (Little and De Louvois, 1999; Faschino et al., 2002). The predominant isolated enterococci strains were Enterococcus faecalis and Enterococcus faecium at percentages of $(10.8 \& 13.5 \%)$ and $(19.0 \& 17.3 \%)$ of total isolates, respectively (Table, 6).

Table (5) showed that E. coli could be isolated from 36.0 and $44.0 \%$ of examined ewe's and goat's milk samples. The E. coli counts $/ \mathrm{ml}$ ranged from $1.0 \times 10$ to $7.0 \times 10$ and 1.0 $\mathrm{x} 10$ to $5.0 \times 10$, with mean counts of $3.0 \times 10$ and $2.1 \times 10$, respectively. Isolated E. coli strains of examined ewe's and goat's milk samples represented 29.7 and $17.3 \%$ of total isolates, respectively (Table, 6). E. coli failed to be detected by (Little and De Louvois, 1999) while, $E$. coli was detected in one sample with a very lower count (Faschino et al., 2002; Dontorou et al., 2003). Higher prevalence was reported by Roberts, (1985) and lower percentage was detected by Rey et al., (2006).

From the obtained results we found that the prevalence of $E$. coli in goat's milk is higher than that of ewe's milk and this finding is in agreement with those reported by (Muehlherr et al., 2003). Accordingly, goats may act as a reservoir of E. coli and goat's milk as well as dairy products may serve as vehicle for the pathogen transmission to humans.

The results listed in Table (6) revealed that the Clostridium perfringens, Campylobacter jejuni, Corynebacterium bovis and Salmonellae failed to be detected in any of examined samples of ewe's and goat's milk. Similar finding were reported by( Abo-Elnaga et al., 1985; Faschino et al., 2002; Muehlherr et al., 2003). While, Roberts, (1985) could detect Campylobacter jejuni in only one samples.

\section{Conclusion}

It is concluded that the differences in count between ewe's and goat's milk may be related to the species differences as well as milking methods. Contamination of milk can be eliminated by following strict hygienic production measures and pasteurization where pasteurization largely eliminates this hazard.

\section{References}

Abo-Elnaga, I. G.; Hessain, A. and Sarhan, H. R. (1985): Bacteria and food poisoning organisms in milk. Nahrung, 29 (4): 375-80.
American Public Health Association (1992): Standard methods for the examination of dairy products. $16^{\text {th }}$ ed., American Public Health Association, New York.

Chapman, G. H. (1945): The significance of sodium chloride in studies of Staphylococci. J. Bacteriol., 50: 201203.

Deinhofer, M. and Pernthaner, A. (1993): Differentiation of Staphylococci from sheep and goat milk samples. Dtsch Tierarztl Wochenschr, 100 (6): 234-6.

DOCE (1994): Directiva 96/71/CE del Consejo, de 13 de diciembere de 1994, por la que se modifica la Directiva 92/46/CEE por la que se establecen las normas sanitarias aplicables a la production y comercializacion de leche cruda, leche tratada termicamente y productos lacteos. Diario Oficial de las Comunidades Europeas (DOCE), pp. 368.

Dontorou, C.; papadopoulou, C.; Filioussis, G.; Economou, V.; Apostolou, I.; Zakkas, G.; Salamoura, A.; Kansouzi-dous, A. and Levidiotou, S. (2003): Isolation of Esherichia coli O157: H7 from foods in Greece. Int. J. Food Microbiol., 15; 82 (3): 273-9.

FAO (2004): Statistical Year book, Food \& Agriculture Organization http: www. fao. Org.

Faschino, R.; Invernizzi, A.; Barucco, R. and Stradiotto, K. (2002): Microbial composition, including the incidence of pathogens, of goat milk from the Bergamo region of Italy during a lactation year. J. Dairy Res., 69 (2): 213-25.

Gelsomino, R.; Vancanneyt, M.; Timothy, M. C. and Jean, S. (2003): Effect of raw milk cheese consumption on the Enterococcal flora of human feces. Appl. Environ. Microbiol., pp.312-319

Haenlein, G. F. W. (2004): Goat milk in human nutrition. Small Rum. Res., 51: 155-163.

Herrero, L. (1999): Aspectos socieconomicos y tecnicos de los quesos tradicionales con Denominacion de Origen Europeos. Ind. Lacteas Espan., 241: 23-33.

Holeckova, B.; Kalinacova, V.; Gondol, J.; Fotta, M.; Holoda, E. and Belickova, E. (2004): Production of enterotoxins by Staphylococcus aureus isolated from sheep's milk. J. Royal Soc. Hlth., 96 (1): 25-30.

Hunt, J. M.; Abetya, C. and Tran, T. (2001): Campylobacter, INFDA Bacteriological analytical Manual on line. $8^{\text {th }}$ ed., rev. A. http: // www. Cfsan. fda. gov/ ebam7. html. Accessed 5, 2005.

James, W. M.; James, E. L.; David, F. B.; James, T. P.; Marvin, T. G.; James, E. G. and John, C. W. (1973): A comparative quality survey of five common market foods in low and high income economic areas. AJPH, 63 (12): 10741079 .

Jayarao, B.M. and Henning, D. R. (2001): Prevalence of foodborne pathogens in raw milk. J. Dairy Sci., 84: 21572162.

Little, C. L. and DeLouvois, J. (1999): Health risks associated with unpasteurized goat's and ewe's milk on retail sale in England and Wales. A PHLS dairy products working group study. Epidemiol. Infect., 122 (3): 403-408.

Miguel, A. F.; Teresa, R. and Manuela, J. (1997): Salt balance in ewe's and goat's milk during storage at chilling and freezing temperature. Agric. Food Chem., 45: 82-88.

Morgan, F.; Jacquet, F.; Micault, S.; Bonnin, V. and Jaubert, A. (2000): Study on the compositional factors involved in the variable sensitivity of caprine milk to hightemperature processing. Int. Dairy J., 10: 113-117.

Muehlherr, J. E.; Zweifel, C.; Corti, S.; Blanco, J. E. and Stephan, R. (2003): Microbiological quality of raw goat's and ewe's bulk-tank milk in Switzerland. J. of Dairy Sci., 86 (12): 3849-56. 
Oxoid (1990): The Oxoid Manual. $6^{\text {th }}$ edition, Unipath. Ltd. U.K.

Rey, J.; Sanchez, S.; Blanco, J. E.; Hermoso de Mendoza, J.; Hermoso de Mendoza, M.; Garcia, A.; Gil, C.; Tejero, N.; Rabino, R. and Alonso, J. M. (2006): Prevalence, serotypes and virulence genes of shiga toxinproducing Escherichia coli isolated from ovine and caprine milk and other dairy products in Spain. Int. J. Food Microbiol., 107 (2): 212-7.

Roberts, D. (1985): Microbiological aspects of goat's milk. A public health laboratory service survey. J. Hygiene, 94 (1): 31-44.

Salmeron, J.; De Vega, C.; Perez-Elortondo, F. J.; Albisu, M. and Barron, L. J. R. (2002): Effect of pasteurization and seasonal variations in the microflora of ewe's milk for cheese making. Food Microbiol., 19: 167174.
Smith, M. C. and Roguinsky, M. (1977): Mastitis and other diseases of goat's udder. J. Am. Vet. Med. Assoc., 1171 (12): 1241-8.

Sorhaug, T. and Stepaniak, L. (1997): Psychrotrophs and their enzymes in milk and dairy products: quality aspects. Trends in food Sci. and Technol. (Vol. 8).

Tamblyn, S. (1986): Raw milk again-Perth District Health Unit. Ontario Dis. Surveill. Rep., 7: 235.

Zeng, S. S. and Escobar, E. N. (1996): Effect of breed and milking method on somatic cell count, standard plate count and composition of goat milk. Small Rum. Res., 19: 169175.

Zweifel, C.; Muehlherr, J. E.; Ring, M. and Stephan, R. (2005): Influence of different factors in milk production on standard plate count of raw small ruminant's bulk tank milk in Switzerland. Small Rum. Res., 58: 63-70.

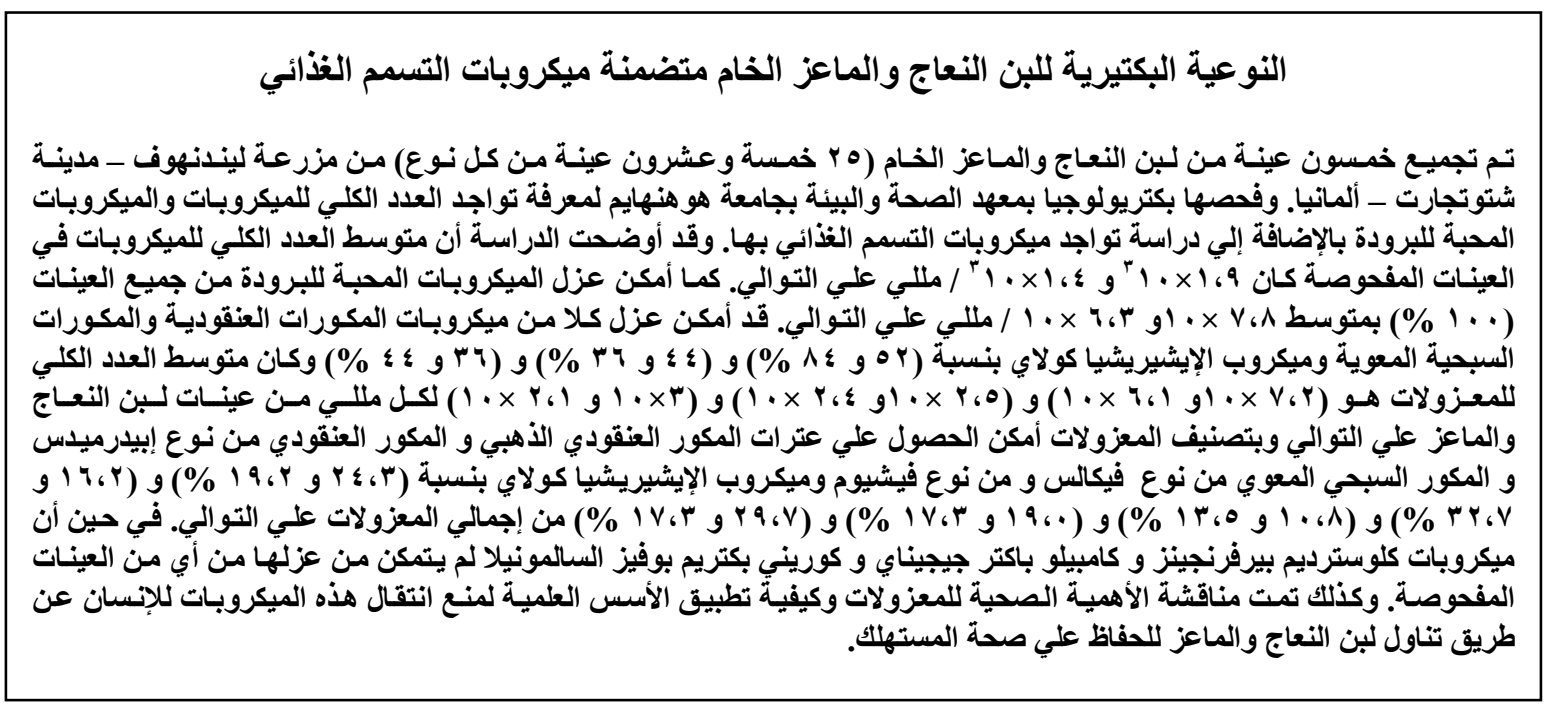

